\title{
Human health risk assessment of cyanide levels in water and tuber crops from Kenyasi, a mining community in the Brong Ahafo Region of Ghana
}

\author{
Edward Ebow Kwaansa-Ansah", Leticia Peace Amenorfe, Edward Kwaku Armah and Francis Opoku
}

\begin{abstract}
Background: Cyanide is among the most harmful substances on Earth and it is harmful to humans and most aquatic life even at low concentrations. Free, total cyanide levels and other physicochemical parameters were determined in fish, cassava, cocoyam, dam and borehole water samples collected from Kenyasi, Ghana. A total of sixteen (16) water samples, five (5) fish samples, twenty (20) cassava and cocoyam tubers were collected from the study area. Free and total cyanide levels were determined using Skalar San ${ }^{++}$Automated Wet Chemistry Analyser with Continuous Flow method.

Results: The mean free cyanide levels in fish, cassava, cocoyam, dam and borehole water samples were 63.09, 33. $26,15.44,0.16$ and $0.18 \mathrm{mg} / \mathrm{L}$, respectively, while the mean total cyanide levels were 93.60, 43.47, 29.62, 21.70 and $25.09 \mathrm{mg} / \mathrm{L}$ in fish, cassava, cocoyam, dam and borehole water samples, respectively. The mean $\mathrm{pH}$ value in fish, cassava, cocoyam, dam and borehole water samples were 6.90,6.46, 6.82, 5.84 and 6.59, respectively. The mean conductivity was 153.64, 156.83, 76.03, 207.39 and 205.99 in fish, cassava, cocoyam, dam and borehole water samples, respectively. Results of two-way Analysis of Variance test showed that the variation in free cyanide levels was significant $(p<0.05)$ in the fish, cassava, cocoyam, dam and borehole water samples. Moreover, the hazard index results via ingestion and dermal contact with children are $>1$, including fish ingestion by an adult. This signifies adverse non-carcinogenic risk. The persistent intake of cassava and cocoyam can probably induce adverse health effects.
\end{abstract}

Conclusions: From the results, it can be concluded that fish, cassava and water samples at Dam 4, Dam 7 and BH1 were not safe for consumption since they recorded values higher than the set limits. Therefore, people are advised not to feed on the cassava product, fish and consume water samples located close to Dam 4, Dam 7 and BH1.

Keywords: Total and free cyanide, Tuber crops, Water, Continuous flow analysis, Physicochemical parameters, Kenyasi-Ghana

\section{Background}

Cyanide is among the most harmful substances on Earth and it is harmful to humans and most aquatic life even at low concentrations (Hosetti 2011). Unlike toxic metals, cyanide is not an element but a compound, which tends to react rapidly with several other chemical elements and is well known to form hundreds of different compounds

\footnotetext{
* Correspondence: eekwaansaansah@yahoo.com

Department of Chemistry, Kwame Nkrumah University of Science and Technology, Kumasi, Ghana
}

(Flynn and Haslem 1995). The in-depth chemistry of cyanide, chemical behaviour in water bodies, as well as toxicity is complex and controlled by numerous factors, such as alkalinity and acidity (Moran 1998). United State Department of Health and Human Services, according to cyanide toxicological profile, regards cyanide as an environmental contaminant (USDHHS 2006).

Even though there are several natural sources of cyanide, such as plants, fungi and bacteria that can be synthesised and secrete it, the most significant sources 
in the environment are municipal wastewaters and industrial wastes (Ubalua 2010). There are three forms of cyanide: free, simple and complex cyanides. Based on temperature and $\mathrm{pH}$ of the environmental medium, free cyanide exists in two forms, such as ionised cyanide and hydrogen cyanide (HCN) (Doudoroff et al. 1966; Mudder et al. 2001). According to the United States Environmental Protection Agency (USEPA) (1984), free cyanide is the most harmful and usage in laboratory toxicity tests. In aqueous solutions, simple cyanide, such as sodium cyanide usually dissociates into salts and free cyanide. Moreover, complex cyanides exist in several forms, however, cyanide-metal complexes, such as nickel cyanide and iron cyanide are the dominant forms in industrial wastewater (Latkowska and Figa 2007).

Human can be exposed to cyanide via drinking water, contaminated food, breathing air and soil contaminated with cyanide. Exposure can also occur by absorption via the skin (dermal absorption), occupational exposure via electroplating or metallurgy (OSHA 1998). Chronic exposure to low concentration of cyanide is supposed to be accountable for several thyrotoxic and neuropathic conditions in humans (Dube and Hosetti 2010). Cyanide can form a stable cytochrome oxidase complex, an enzyme that facilitates electrons transfer within the mitochondria cells through the fabrication of adenosine triphosphate (Yen et al. 1995). Exposure to HCN causes bleeding, dermatitis, scarlet rash, itching, nose irritations and papules (Nagasawa et al. 2007; Pritchard 2007).

Fish and aquatic invertebrates are sensitive to cyanide exposure. Moreover, the sensitivity of aquatic organisms to cyanide exposure is species-specific, which is influenced by water oxygen content, temperature and $\mathrm{pH}$, as well as the condition and life stage of the organism (Hosetti 2011). Hydrological factors, such as temperature, total dissolved solids (TDS), $\mathrm{pH}$ and conductivity can affect the decomposition rate of cyanide-related compounds in water resources (Sawaraba and Rao 2015). WHO has set $0.2 \mathrm{mg} / \mathrm{L}$ as the maximum limit for cyanide in water and $10 \mathrm{mg} / \mathrm{kg}$ in cassava (Wilson 1983). Research has shown that cyanide affects individuals who have regular longterm consumption of cassava (Flynn and Haslem 1995). To the best of our knowledge, there has been no report on the levels of cyanide in tuber crops, such as cassava and cocoyam in Kenyasi, a Mining Community in the Brong Ahafo Region of Ghana. Moreover, people living around mining sites rely on these crops as the major source of food consumption. However, since the plants take up cyanide from soils polluted by organic salts with cyanide ion from mining activities and industrial effluents, their effects on consumers need to be addressed. Therefore, the main aim this study was to evaluate the levels of free and total cyanide in fish, water, cassava and cocoyam in Kenyasi, a mining community in the Brong-Ahafo region of Ghana.

\section{Methods \\ Study area}

Kenyasi is located in the Brong Ahafo Region of Ghana. The Ahafo mine located at Kenyasi is in the tropical, cocoa-growing region of mid-western Ghana, which is about $290 \mathrm{~km}$ northwest of Accra and contributes about $8 \%$ of Newmont's global equity gold sales (Newmont Mining Corporation 2006). Kenyasi, where the Ahafo mine is located produced approximately 446,000 equity ounces of gold with about 9.7 million ounces of gold in reserves, which is enough to actively mine for nearly 20 years (Newmont Mining Corporation 2006). Kenyasi is the capital of the Asutifi district in the Brong Ahafo region of Ghana. The Asutifi District is one of the Nineteen (19) districts in Brong Ahafo located between latitudes $6^{\circ} 40^{\prime \prime}$ and $7^{\circ} 15^{\prime \prime}$ North and Longitudes $2^{\circ} 15^{\prime \prime}$ and $2^{\circ} 45^{\prime \prime}$ West sharing boundaries with Sunyani District in the North, Tano South District to the North East, Dormaa District to North West, Asunafo North and South Districts in the South West and Ahafo Ano South and North Districts (Ashanti Region) in the South East (Government of Ghana 2009). The region lies in the forest zone. Kenyasi is a major cocoa and timber producing area. The northern part of the region lies in the savannah zone with a major production of grain and tuber. The total population of the region is approximately $1,815,408$, representing $9.6 \%$ of the country's population. The main occupation in the region is agriculture, which employs about $68.6 \%$ of the economically active population.

The Asutifi District is one of the smallest in the Brong Ahafo Region with a total of 117 settlements and land surface area of $1500 \mathrm{~km}^{2}$ (sq.km) (Government of Ghana 2009). Kenyasi is about $50 \mathrm{~km}$ from Sunyani, the regional capital of Brong Ahafo (Government of Ghana 2009). The Asutifi District has abundant natural resources including areas of forestry products, the soil of high agronomic value, sand, clay and mineral deposits, such as gold, bauxite and diamond (Government of Ghana 2009). Topographically, Kenyasi lies within the forest dissected plateau with an average height of about $700 \mathrm{ft}$ above sea level and the highest point is a chain of mountains, while the lowest part is along the river basins (Government of Ghana 2009). Geologically, the area is covered by rocks of Dahomeyan and formations, which are known to be Bauxite, manganese and goldbearing rocks (Government of Ghana 2009). This explains why currently gold is being mined in Kenyasi. Moreover, there are large areas of forest reserves, such as the Desiri Forest Reserve, Bia Tam Forest Reserve, Biaso Shelter Belt, Goa Forest Reserve and Asukese 
Forest Reserve, which together covered a total of about 475.63 sq.km (Government of Ghana 2009). The current operation of gold mining activities by Newmont Ghana Gold Limited has created severe anxiety about the implications of the mining activities on the local economy.

\section{Sample collection}

A total of sixteen (16) water samples was collected from the study area of which seven (7) were from the dam, two (2) from the surface water to serve as a control for the dam and seven (7) from boreholes close to the mining area during March 2017. The $\mathrm{pH}$ and electrical conductivity (EC) of the water samples were measured in situ using Yogokawa $\mathrm{pH}$ meter and Orion Thermoscientific meter, respectively. A total of five (5) fish samples were sampled from the dam with hook and line into a black polyethene bag. They were then kept in an ice-cooled container, transported to the laboratory and refrigerated prior to analysis. The Department of Fisheries, Faculty of Renewable and Natural Resources, Kwame Nkrumah University of Science and Technology, Kumasi-Ghana, identified the fish samples. The samples were found to belong to the Oreochromis niloticus. Three Oreochromis niloticus were obtained from a pond in Kumasi to serve as a control (Fish C). A total of twenty (20) randomly selected cassava and cocoyam tubers were harvested from local farms close to the mining area. This was done by picking four samples from four divided portions of a farm. In all, four different farms were considered each for cassava and cocoyam. Adhering soils were thoroughly washed with distilled water. The cassava and cocoyam samples were then labelled. Three samples, each of cassava and cocoyam were collected from a non-mining area (Hwidiem) treated the same way and labelled $\mathrm{CvC}$ for cassava and $\mathrm{CyC}$ for cocoyam to serve as a control. The cassava and cocoyam samples were wrapped in a black polythene bag in an ice-cooled container and transported to the laboratory for further analysis.

\section{Analysis}

\section{Determination of hydrogen cyanide}

Total and free cyanide concentrations were determined in the water, fish, cocoyam and cassava samples from Kenyasi and Hwidiem. The solid samples were first distilled before the cyanide concentrations were determined. The distillation method was adopted for the treatment of the solid samples (fish, cassava and cocoyam) to bring into solution the hydrogen cyanide for the continuous flow analysis (ISO 14403). Approximately $40.0 \mathrm{~g}$ each fish, cassava and cocoyam samples were blended with a $250 \mathrm{~mL}$ distilled water and the mixture was transferred to a $500 \mathrm{~mL}$ round bottom flask. To each sample in the round bottom flask, a $12.5 \mathrm{~mL}$ conc. (98\%) sulphuric acid and $5 \mathrm{~mL}$ of $2.5 \mathrm{M}$ magnesium chloride hexahydrate were added. A $12.5 \mathrm{~mL}$ aliquot of $1.25 \mathrm{~N}$ sodium hydroxide were put into the glass distillate collector and the delivery tube was positioned such that the tip was in contact with the sodium hydroxide solution to enable it to trap the hydrogen cyanide released without any escape. The sample mixture in the round bottom flask was heated at a temperature of $100{ }^{\circ} \mathrm{C}$ in a heating mantle for $1 \mathrm{~h}$. The heating mantle was then turned off, the distillate cooled for $20 \mathrm{~min}$, poured into a $250 \mathrm{~mL}$ volumetric flask and diluted to the mark with distilled water. Blanks were prepared with the same procedure without the sample. The samples were kept in the freezer until the final determination using the Skalar $\mathrm{San}^{++}$Automated Wet Chemistry Analyser from Breda, Netherlands. The automated procedure for the determination of total cyanide involves the decomposition of the complex bound cyanide in a continuously flowing stream at $\mathrm{pH}$ of 3.8 using UV light. A UV-B light lamp (312 nm) and decomposition spiral of borosilicate glass were used to filter out the UV light with a wavelength $<290 \mathrm{~nm}$ to prevent the conversion of thiocyanate into cyanide. The hydrogen cyanide present at $\mathrm{pH}$ of 3.8 is separated by the in-line distillation at $125{ }^{\circ} \mathrm{C}$ under vacuum. The hydrogen cyanide produced react with chloramine- $T$ to form cyanogens chloride, which then reacts with 4-pyridine carboxylic acid and 1,3-dimethyl barbituric acid to give a red colour with a maximum absorbance at $600 \mathrm{~nm}$. The determination was repeated for each sample twice and their means were taken. The instrument has a detection limit of 0.03 .

\section{Conductivity and $\mathrm{pH}$ measurement of the solid samples}

About $20 \mathrm{~g}$ of each solid sample was ground into a $500 \mathrm{~mL}$ pyrex beaker, followed by the addition of a $100 \mathrm{~mL}$ distilled water and stirred for $10 \mathrm{~min}$ with a magnetic stirrer to ensure complete homogeneity. The mixture was then filtered into a small sterilised plastic container and the $\mathrm{pH}$ of the filtrate was determined by immersing the $\mathrm{pH}$ electrode into the filtrates of the solid samples. The $\mathrm{pH}$ measurements were taken using Yogokawa pH meter from Musashino-shi, Tokyo. A steady reading was recorded in each case. The electrodes were washed thoroughly with distilled water after every determination to avoid cross-contamination. For each sample, the $\mathrm{pH}$ determinations were made in triplicate and the mean taken to represent the $\mathrm{pH}$ of the sample. The conductivity readings of both the solid samples were also taken in the same manner using the Orion Thermo Scientific meter from Fairland, Johannesburg.

Determination of moisture content of cassava and cocoyam About $5 \mathrm{~g}$ of each cassava and cocoyam samples were grated into a crucible and dried in an oven at a temperature 
of $105{ }^{\circ} \mathrm{C}$ for $72 \mathrm{~h}$. The samples were then cooled in a desiccator and then reweighed. The drying process was repeated at the same temperature at time intervals of $1 \mathrm{~h}$ until a constant weight was recorded for each of them.

\section{Human health risk assessment}

Non-carcinogenic health risk models presented by the United States Environmental Protection Agency, have been proven successful and are now adopted globally. Humans can be exposed to cyanide through several pathways, as given in Table 1 (USEPA IRIS 2011).

The average daily dose (ADD) of cyanide via ingestion $\left(\mathrm{ADD}_{\text {ing }}\right)$ and dermal contact $\left(\mathrm{ADD}_{\text {derm }}\right)$ for both adult and children are evaluated following Eqs. (1), (2) and (3):

$$
\begin{aligned}
& \mathrm{ADD}_{\text {ing }}=\frac{\mathrm{C} x \operatorname{IngR} x \mathrm{EF} \times \mathrm{ED}}{\mathrm{BW} x \mathrm{AT}} \\
& \mathrm{ADD}_{\text {dermal }}=\frac{\mathrm{C} x \mathrm{SA} x \mathrm{AF} x \mathrm{ABF} x \mathrm{EF} x \mathrm{ED}}{\mathrm{BW} x \mathrm{AT}}
\end{aligned}
$$

The exposure factors and values utilised in the evaluation of health risk evaluation are shown in Table 2 .

The non-carcinogenic risk can be expressed as HQ using Eq. (4).

$$
\mathrm{HQ}=\frac{\mathrm{ADD}}{\mathrm{RfD}}
$$

where $\mathrm{RfD}$ is the estimated maximum permissible risk imposed on humans via daily exposure. The RfD of cyanide is $6.3 \times 10^{-4} \mathrm{mg} \mathrm{kg}^{-1}$ day $^{-1}$ (USEPA IRIS 2011). If $\mathrm{HQ}<1$, signifies no adverse effects, while $\mathrm{HQ}>1$, represent adverse effects (USEPA IRIS 2011).

To estimate the human health risk from consuming cyanide-contaminated fish, the target hazard quotient (THQ) was calculated as follows (USEPA IRIS 2011):

$$
\mathrm{THQ}=\frac{\mathrm{C} x \operatorname{IngR} x \mathrm{EF} x \mathrm{ED} x \mathrm{Cf}}{\mathrm{BW} x \mathrm{AT} x \mathrm{RfD}} \times 10^{-3}
$$

where Cf is the conversion factor (0.208).

Table 1 Daily intake equation through several exposure routes

\begin{tabular}{llll}
\hline Medium & Sources of cyanide & Exposure route & $\begin{array}{l}\text { Calculation } \\
\text { formula }\end{array}$ \\
\hline Water & Cyanide in water & $\begin{array}{l}\text { Ingestion } \\
\text { Dermal contact }\end{array}$ & $\begin{array}{l}\mathrm{ADD}_{\text {ing-water }} \\
\mathrm{ADD}_{\text {derm - water }}\end{array}$ \\
$\begin{array}{l}\text { Crops (Cassava } \\
\text { and cocoyam) }\end{array}$ & Cyanide in crops & Ingestion & $\mathrm{ADD}_{\text {ing-crops }}$ \\
Fish & Cyanide in fish & Ingestion & $\mathrm{ADD}_{\text {ing-fish }}$ \\
\hline
\end{tabular}

\section{Statistical analysis}

The results recorded were analysed using Analysis of variance (ANOVA) with the aid of MINI TAB. The Tukey method, which is also known as the Tukey's range test was used to determine the least significant difference (LSD) at $p<0.05$ between the mean values of the measured parameters. The Tukey method is a singlestep multiple comparison statistical test (Morrison et al. 2013). This method is applicable for pairwise comparisons. The Tukey method assumes independence of the observations being tested, as well as equal variation across observations. The Tukey method can be used on raw data or in conjunction with a post-hoc analysis to analyse data that are significantly different from each other.

\section{Results and discussion}

\section{Cyanide levels in the water samples}

The analytical result of free and total cyanide level in the seven borehole and dam water samples collected from Kenyasi are shown in Table 3. Physicochemical parameters, such as $\mathrm{pH}$, temperature, EC and TDS in the water samples are also presented in Table 3.

The free cyanide levels of the dam and borehole water samples range from $0.11 \pm 0.01$ to $0.22 \pm 0.02 \mathrm{mg} / \mathrm{L}$ and $0.15 \pm 0.01$ to $0.23 \pm 0.02 \mathrm{mg} / \mathrm{L}$, respectively (Table 1 ). Moreover, the free cyanide levels of the borehole samples appeared to be higher than those of the dam samples because cyanide might leach into the subsurface groundwater and hence, cause an increase in the cyanide concentration. The free cyanide levels of the control dam water samples were averagely greater compared to the borehole control samples and fall below the acceptable level. Moreover, the free cyanide levels at almost all the sampling sites, except at Dam 4, Dam 7 and BH1 were below the maximum contaminant level of $0.2 \mathrm{mg} \mathrm{L}^{-1}$ established by USEPA (USEPA 2002) and the Ghana Environmental Protection Agency (EPA). According to these guidelines, the free cyanide concentrations were found to be in safe levels owing to the low evaporation rates of cyanide in the water resources. The free cyanide concentration recorded in the present study was relatively lower than those found in the surface water of Obuasi area (Ndur and Amegbey 2013) and Bogoso (Obiri et al. 2007), all in Ghana owing to extreme gold mining activities in these areas. There was a significant difference $(p<0.05)$ in free cyanide levels between the dam and borehole water samples.

The total cyanide level of the dam samples ranged from $20.52 \pm 0.09$ to $22.30 \pm 0.27$, whereas those of the borehole samples were between $22.82 \pm 0.03$ and $27.05 \pm 1.17 \mathrm{mg} / \mathrm{L}$ (Table 1 ). The total cyanide concentration in the dam and borehole water samples were higher than the Ghana EPA permissible limit of $1.0 \mathrm{mg} / \mathrm{L}$. Significantly, the total cyanide concentration 
Table 2 Exposure factors and reference value of parameters used for the human health risk evaluation of cyanide

\begin{tabular}{|c|c|c|c|c|c|}
\hline \multirow[t]{2}{*}{ Factor } & \multirow[t]{2}{*}{ Definition } & \multirow[t]{2}{*}{ Unit } & \multicolumn{2}{|l|}{ Value } & \multirow[t]{2}{*}{ Reference } \\
\hline & & & Children & Adult & \\
\hline C & cyanide concentration & mg/kg, mg/L & & & This study \\
\hline $\operatorname{lngR}$ & Ingestion rate & mg/day & 200 & 100 & USEPA (2011) \\
\hline EF & Exposure frequency & days/year & 350 & 350 & Environmental site assessment guideline (2009) \\
\hline ED & Exposure duration & years & 6 & 24 & USEPA (2011) \\
\hline BW & Body weight & $\mathrm{kg}$ & 15 & 55.9 & Environmental site assessment guideline (2009) \\
\hline AT & Average time & days & $365 \times \mathrm{ED}$ & $365 \times \mathrm{ED}$ & USEPA (1989) \\
\hline SA & Exposure skin surface area & $\mathrm{cm}^{2}$ & 1600 & 4350 & Environmental site assessment guideline (2009) \\
\hline AF & Skin adherence factor & $\mathrm{mg} / \mathrm{cm}$ day & 0.2 & 0.7 & USEPA (1993) \\
\hline$A B F$ & Dermal absorption factor & no unit & 0.001 & 0.001 & Chabukdhara and Nema (2013) \\
\hline
\end{tabular}

of the borehole water samples was higher than those of the dam samples due to the complex nature of the cyanide species in the borehole water samples. A significant difference $(p<0.05)$ were also found between the control samples of the dam samples and those of the borehole samples.

Since the decomposition rate of cyanide-related compounds in water is affected by TDS, $\mathrm{pH}$, temperature and conductivity, water samples polluted with cation hydrolysis of dissolved ions or acid mine drainage makes the water acidic. The $\mathrm{pH}$ value of dam water samples ranged from $3.98 \pm 0.02$ to $6.21 \pm 0.01$, which fall within the acidic range. The control samples from Hwidiem,
SW1 and SW2 gave $\mathrm{pH}$ values of $6.96 \pm 0.02$ and $6.99 \pm 0.01$ respectively, which were almost neutral. The $\mathrm{pH}$ of the control samples was more acidic compared to that of the dam samples since the water was contained and not properly mixed. An increase in acidity increases the dissociation of cyanide compounds, which also increases the free cyanide concentrations in the water resources (Meeussen et al. 1994). This explains why samples with the lowest $\mathrm{pH}$ values recorded the highest free cyanide concentrations. The $\mathrm{pH}$ values of the borehole samples ranged from $5.97 \pm 0.04$ to $7.02 \pm 0.03$. The borehole water samples were less acidic compared to the dam water samples, which might explain why the

Table 3 Analysis result of dam, borehole and the controls samples

\begin{tabular}{|c|c|c|c|c|c|c|c|}
\hline Sample & $\mathrm{pH}$ & Cond. $(\mu \mathrm{S} / \mathrm{cm})$ & Temp $\left({ }^{\circ} \mathrm{C}\right)$ & TDS (mg/L) & TSS (\%) & $\mathrm{CN}^{-}(\mathrm{mg} / \mathrm{L})$ & Total $\mathrm{CN}^{-}(\mathrm{mg} / \mathrm{L})$ \\
\hline Dam 1 & $5.88 \pm 0.03$ & $222.7 \pm 5.42$ & $30.0 \pm 0.2$ & $65 \pm 4.0$ & $525 \pm 10.9$ & $0.17 \pm 0.02$ & $22.25 \pm 0.02$ \\
\hline Dam 2 & $6.21 \pm 0.01$ & $214.2 \pm 7.12$ & $30.8 \pm 0.1$ & $63 \pm 2.1$ & $611 \pm 15.4$ & $0.11 \pm 0.01$ & $22.13 \pm 0.03$ \\
\hline Dam 3 & $6.20 \pm 0.02$ & $210.0 \pm 5.42$ & $30.2 \pm 0.1$ & $61 \pm 4.0$ & $571 \pm 12.4$ & $0.12 \pm 0.02$ & $22.30 \pm 0.27$ \\
\hline Dam 4 & $4.11 \pm 0.01$ & $274.7 \pm 6.00$ & $30.5 \pm 0.2$ & $69 \pm 3.0$ & $634 \pm 15.7$ & $0.21 \pm 0.02$ & $21.71 \pm 0.03$ \\
\hline Dam 5 & $6.02 \pm 0.01$ & $117.1 \pm 6.12$ & $30.1 \pm 0.1$ & $54 \pm 5.0$ & $514 \pm 10.6$ & $0.15 \pm 0.01$ & $21.47 \pm 0.05$ \\
\hline Dam 6 & $5.95 \pm 0.04$ & $111.5 \pm 7.10$ & $30.3 \pm 0.3$ & $52 \pm 3.0$ & $504 \pm 12.4$ & $0.14 \pm 0.01$ & $21.54 \pm 0.04$ \\
\hline Dam 7 & $3.98 \pm 0.02$ & $301.5 \pm 10.41$ & $30.5 \pm 0.1$ & $70 \pm 5.0$ & $617 \pm 8.51$ & $0.22 \pm 0.02$ & $20.52 \pm 0.09$ \\
\hline SW 1 & $6.96 \pm 0.02$ & $119.5 \pm 5.70$ & $22.7 \pm 0.2$ & $55 \pm 4.0$ & $245 \pm 14.5$ & $0.09 \pm 0.01$ & $12.38 \pm 0.01$ \\
\hline SW 2 & $6.99 \pm 0.01$ & $118.9 \pm 8.42$ & $22.1 \pm 0.2$ & $52 \pm 2.0$ & $224 \pm 8.7$ & $0.10 \pm 0.01$ & $13.57 \pm 0.02$ \\
\hline \multicolumn{8}{|c|}{ Borehole } \\
\hline $\mathrm{BH} 1$ & $5.97 \pm 0.04$ & $298.0 \pm 10.6$ & $26.9 \pm 0.1$ & $65 \pm 0.1$ & $401 \pm 8.4$ & $0.23 \pm 0.02$ & $26.07 \pm 0.02$ \\
\hline $\mathrm{BH} 2$ & $6.31 \pm 0.06$ & $261.5 \pm 9.01$ & $26.4 \pm 0.0$ & $63 \pm 0.5$ & $355 \pm 6.2$ & $0.17 \pm 0.02$ & $24.43 \pm 0.98$ \\
\hline $\mathrm{BH} 3$ & $6.38 \pm 0.02$ & $221.1 \pm 10.2$ & $26.7 \pm 0.1$ & $58 \pm 0.4$ & $445 \pm 8.4$ & $0.16 \pm 0.01$ & $27.05 \pm 1.17$ \\
\hline $\mathrm{BH} 4$ & $6.80 \pm 0.02$ & $170.2 \pm 6.40$ & $26.0 \pm 0.0$ & $51 \pm 0.2$ & $330 \pm 4.6$ & $0.16 \pm 0.02$ & $25.57 \pm 0.02$ \\
\hline $\mathrm{BH} 5$ & $6.72 \pm 0.07$ & $172.0 \pm 5.00$ & $26.3 \pm 0.1$ & $55 \pm 0.4$ & $505 \pm 7.1$ & $0.17 \pm 0.01$ & $25.55 \pm 0.40$ \\
\hline $\mathrm{BH} 6$ & $6.93 \pm 0.01$ & $202.3 \pm 5.12$ & $26.4 \pm 0.1$ & $60 \pm 0.5$ & $321 \pm 9.1$ & $0.19 \pm 0.01$ & $24.15 \pm 0.08$ \\
\hline $\mathrm{BH} 7$ & $7.02 \pm 0.03$ & $116.8 \pm 8.41$ & $26.8 \pm 0.1$ & $49 \pm 0.4$ & $312 \pm 4.3$ & $0.15 \pm 0.01$ & $22.82 \pm 0.03$ \\
\hline Cw1 & $7.05 \pm 0.01$ & $109.0 \pm 5.10$ & $26.2 \pm 0.2$ & $24 \pm 0.3$ & $241 \pm 4.1$ & $0.09 \pm 0.01$ & $3.13 \pm 0.010$ \\
\hline Cw2 & $7.21 \pm 0.01$ & $88.2 \pm 4.21$ & $26.1 \pm 0.1$ & $26 \pm 0.1$ & $235 \pm 5.0$ & $0.09 \pm 0.00$ & $2.96 \pm 0.020$ \\
\hline
\end{tabular}

Cond. - conductivity, Temp - Temperature, TDS - Total dissolved solids, TSS - Total suspended solids 
free cyanide concentrations were high for high $\mathrm{pH}$ water samples. There was a significant difference $(p<0.05)$ between all the $\mathrm{pH}$ values for the dam and borehole water samples.

The conductivity values for the dam samples $(111.5 \pm 7.10-301.5 \pm 10.41 \mu \mathrm{S} / \mathrm{cm})$ were within a wider range than those of the borehole samples $(116.8 \pm 8.41-298.0 \pm 10.6 \mu \mathrm{S} / \mathrm{cm})$. Thus, the ions in the dam samples move more freely than the borehole samples. Moreover, the conductivity increase with increasing concentrations of the cyanide ions present. The conductivity values were significantly different $(p<0.05)$.

The total dissolved solids concentration for the dam and borehole water samples ranged from $52 \pm 3.0$ $70 \pm 5.0 \mathrm{mg} / \mathrm{L}$ to $49 \pm 0.4-65 \pm 0.1 \mathrm{mg} / \mathrm{L}$, respectively. The TDS of the control samples of the dam $(55 \pm 4.0$ to $52 \pm 2.0 \mathrm{mg} / \mathrm{L}$ ) were higher than the borehole samples $(24 \pm 0.3$ to $26 \pm 0.1 \mathrm{mg} / \mathrm{L})$. This indicates that the surface water contains higher levels of TDS compared to the groundwater because of its large area exposed to the environment and the high dissociation probability owing to high $\mathrm{pH}$ and temperature.

\section{Cyanide levels in the fish samples}

Among the aquatic organisms, fish is the most cyanidesensitive with high mortality rate due to the free cyanide concentrations of $>20 \mu \mathrm{g} / \mathrm{L}$ (Eisler and Wiemeyer 2004). The toxicity of cyanide on aquatic organisms relies on numerous factors, such as water $\mathrm{pH}$ and temperature. The free and total cyanide levels in the fish samples are displayed in Table 4.

The free and total cyanide levels ranged from $55.81 \pm 4.50$ to $71.69 \pm 2.74 \mathrm{mg} / \mathrm{kg}$ and $84.31 \pm 2.12$ to $110.56 \pm 4.00 \mathrm{mg} / \mathrm{Kg}$, respectively (Table 4). Free cyanide is acutely and instantaneously toxic to aquatic organisms and humans. The cyanide level in the fish samples was above the $0.01-0.10 \mathrm{mg} / \mathrm{L}$ reported by other studies (Govind 2013). These levels can kill some sensitive animal's species in the water systems (Govind 2013). Fish are almost one thousand times more sensitive to cyanide compared to humans (Ikuta et al. 1999). Exposure to sublethal concentrations of copper cyanide

Table 4 Analysis results of dam and control fish samples

\begin{tabular}{lllll}
\hline Sample & $\mathrm{pH}$ & Cond. $(\mu \mathrm{S} / \mathrm{cm})$ & $\mathrm{CN}^{-}(\mathrm{mg} / \mathrm{kg})$ & Total CN $^{-}(\mathrm{mg} / \mathrm{kg})$ \\
\hline Fish 1 & $6.88 \pm 0.01$ & $201.2 \pm 5.00$ & $59.81 \pm 4.10$ & $79.44 \pm 4.20$ \\
Fish 2 & $6.87 \pm 0.02$ & $215.8 \pm 9.20$ & $61.50 \pm 2.04$ & $103.44 \pm 5.12$ \\
Fish 3 & $6.69 \pm 0.01$ & $117.4 \pm 4.64$ & $71.69 \pm 2.74$ & $110.56 \pm 4.00$ \\
Fish 4 & $7.14 \pm 0.01$ & $119.0 \pm 9.00$ & $55.81 \pm 4.50$ & $84.31 \pm 2.12$ \\
Fish 5 & $6.90 \pm 0.02$ & $114.8 \pm 6.57$ & $66.63 \pm 3.24$ & $90.25 \pm 3.11$ \\
Fish C & $7.22 \pm 0.01$ & $111.0 \pm 5.41$ & $<0.03 \pm 0.01$ & $<0.03 \pm 0.01$ \\
\hline
\end{tabular}

Fish C-control fish sample caused a significant dose-dependent adjustment, as well as carbohydrate metabolism in the tissues of $C$. catla (Hosetti 2011). Exposure to high levels of cyanide might lead to the mortality of fish (Vaz et al. 2012). The effect of cyanide on fish relies on the cyanide concentration during exposure, the length of time of the exposure and the size of the species (Bruckner and Roberts 2008). There was a significant difference $(p<0.05)$ between free and total cyanide levels in the fish samples.

The $\mathrm{pH}$ values of the fish samples ranged from $6.69 \pm 0.01$ to $7.14 \pm 0.01$. Conversely, the control sample (fish C) with a pH of $7.22 \pm 0.01$ had both free and total cyanide levels below the detection limit. The surrounding environment normally influences the $\mathrm{pH}$ of a fish, thus when the $\mathrm{pH}$ is too low, it turns out to be harmful to the fish (Ikuta et al. 1992). Subsequently, the chloride cells within the gill tissue of the fish take up hydrogen carbonate from the outside to neutralise the $\mathrm{H}^{+}$ion flowing through the body (Ikuta 1999). Thus, there is a higher possibility for the fish to take up $\mathrm{CN}^{-}$ ions if the surroundings of the fish are contaminated and predominated with $\mathrm{CN}^{-}$rather than $\mathrm{HCO}_{3}^{-}$. Under typical conditions of natural waters with $\mathrm{pH} 6.0-8.5$ and temperature $4-10{ }^{\circ} \mathrm{C}$, more than $90 \%$ of cyanide normally exists as molecular HCN (APHA 1998). The $\mathrm{pH}$ values for all the fish samples were significantly different $(p<0.05)$.

The conductivity values increased from $114.8 \pm 6.57$ to $215.8 \pm 9.20 \mu \mathrm{S} / \mathrm{cm}$ (Table 4). The two major factors influencing the composition of ions (bicarbonate, sulphate, calcium, sodium, and silica) in water resources are geology and precipitation/evaporation ratios (Weber-Scannell and Duffy 2007). Changes in the composition of ions can occur via several anthropogenic sources, such as industrial waste and mining activities and this can increase conductivity (Fillo et al. 1992). There was also a significant difference $(p<0.05)$ between the levels of conductivity.

\section{Cyanide levels in the cassava samples}

The result of cassava samples in terms of $\mathrm{pH}$, conductivity, moisture content, free cyanide concentration and total cyanide concentration are presented in Table 5 .

The free cyanide levels in the cassava samples ranged from $5.25 \pm 0.02$ to $93.88 \pm 5.14 \mathrm{mg} / \mathrm{kg}$ (Table 5) with $70 \%$ of the cassava samples contain cyanide levels far above the set limit of $10 \mathrm{mg} / \mathrm{kg}$ (Wilson 1983). This indicates that the cassava samples with cyanide levels above the set limit could pose serious effect to human health. Cassava contains potentially toxic levels of cyanogenic glucosides, made up of lotaustralin (5\%) and linamarin (95\% of total cyanogen content). Linamarin exist in all cassava tissues (Balagopalan et al. 1988) and is synthesised from the amino acid valine. Cyanogenesis is initiated in physically damaged cassava tissues since cyanogenic and cyanogens 
Table 5 Analysis results of cassava samples (CvC - control cassava sample)

\begin{tabular}{|c|c|c|c|c|c|}
\hline Sample & $\mathrm{pH}$ & Cond. $(\mu \mathrm{S} / \mathrm{cm})$ & Moisture content (\%) & $\mathrm{CN}^{-}(\mathrm{mg} / \mathrm{kg})$ & Total $\mathrm{CN}^{-}(\mathrm{mg} / \mathrm{kg})$ \\
\hline $\mathrm{CVF1}(\mathrm{I})$ & $6.65 \pm 0.02$ & $231.0 \pm 8.43$ & $53.90 \pm 0.80$ & $16.63 \pm 0.68$ & $17.13 \pm 0.07$ \\
\hline CVF1(II) & $6.11 \pm 0.04$ & $213.8 \pm 6.42$ & $56.30 \pm 0.52$ & $50.44 \pm 3.14$ & $51.38 \pm 4.17$ \\
\hline CVF1(III) & $6.88 \pm 0.02$ & $113.5 \pm 5.24$ & $54.60 \pm 0.60$ & $5.25 \pm 0.02$ & $8.06 \pm 0.01$ \\
\hline CVF1(IV) & $6.55 \pm 0.01$ & $118.7 \pm 5.00$ & $53.30 \pm 0.45$ & $15.75 \pm 0.17$ & $16.25 \pm 0.07$ \\
\hline $\operatorname{CvF2}(\mathrm{I})$ & $6.76 \pm 0.02$ & $118.2 \pm 6.24$ & $55.90 \pm 0.60$ & $9.19 \pm 0.07$ & $9.94 \pm 0.06$ \\
\hline CVF2(II) & $6.20 \pm 0.01$ & $191.6 \pm 6.27$ & $54.10 \pm 0.95$ & $44.56 \pm 0.85$ & $49.00 \pm 2.15$ \\
\hline CVF2(III) & $6.67 \pm 0.01$ & $199.4 \pm 7.20$ & $59.20 \pm 1.52$ & $10.31 \pm 0.12$ & $10.63 \pm 0.07$ \\
\hline CVF2(IV) & $6.77 \pm 0.01$ & $94.3 \pm 4.02$ & $54.90 \pm 2.00$ & $6.25 \pm 0.04$ & $6.75 \pm 0.03$ \\
\hline CVF3(I) & $6.33 \pm 0.01$ & $120.9 \pm 7.07$ & $52.80 \pm 0.95$ & $34.80 \pm 1.24$ & $35.81 \pm 1.20$ \\
\hline CVF3(II) & $6.05 \pm 0.03$ & $114.5 \pm 5.80$ & $53.00 \pm 0.83$ & $86.50 \pm 4.85$ & $123.63 \pm 5.14$ \\
\hline CVF3(III) & $5.92 \pm 0.02$ & $187.2 \pm 6.17$ & $53.40 \pm 0.74$ & $93.88 \pm 5.14$ & $165.56 \pm 6.89$ \\
\hline CVF3(IV) & $6.01 \pm 0.02$ & $182.0 \pm 6.24$ & $55.80 \pm 1.02$ & $88.38 \pm 5.23$ & $128.63 \pm 8.12$ \\
\hline CVF4(I) & $5.96 \pm 0.03$ & $134.3 \pm 5.67$ & $55.50 \pm 1.10$ & $93.56 \pm 4.20$ & $132.63 \pm 10.1$ \\
\hline CVF4(II) & $6.14 \pm 0.02$ & $209.5 \pm 8.72$ & $58.00 \pm 1.20$ & $37.31 \pm 1.52$ & $39.19 \pm 4.24$ \\
\hline CVF4(III) & $6.84 \pm 0.01$ & $239.5 \pm 6.27$ & $54.80 \pm 0.67$ & $9.63 \pm 0.03$ & $10.69 \pm 0.09$ \\
\hline CVF4(IV) & $6.89 \pm 0.01$ & $130.4 \pm 5.00$ & $51.20 \pm 0.88$ & $6.19 \pm 0.04$ & $6.56 \pm 0.03$ \\
\hline CVF5(I) & $6.72 \pm 0.01$ & $114.7 \pm 5.42$ & $55.40 \pm 1.24$ & $11.06 \pm 0.05$ & $11.19 \pm 0.10$ \\
\hline CVF5(II) & $6.86 \pm 0.02$ & $164.9 \pm 7.87$ & $54.30 \pm 0.65$ & $9.75 \pm 0.07$ & $10.25 \pm 0.04$ \\
\hline CVF5(III) & $6.74 \pm 0.04$ & $132.8 \pm 10.41$ & $52.40 \pm 1.70$ & $11.69 \pm 1.12$ & $11.88 \pm 0.08$ \\
\hline CVF5(IV) & $6.24 \pm 0.04$ & $125.3 \pm 8.07$ & $58.42 \pm 1.34$ & $24.06 \pm 1.54$ & $24.31 \pm 0.18$ \\
\hline $\mathrm{CrC}$ & $7.01 \pm 0.02$ & $111.2 \pm 4.20$ & $55.80 \pm 0.97$ & $4.75 \pm 0.02$ & $4.94 \pm 0.03$ \\
\hline
\end{tabular}

Cond. - conductivity

enzymes are differently compartmentalised in the cell (White et al. 1994). Therefore, after tissue maceration, linamarin is released from vacuoles, which then broke down to acetone cyanohydrin and glucose by linamarase (White et al. 1994). Acetone cyanohydrin can spontaneously decompose into acetone and cyanide with $\mathrm{pH}$ and temperatures above 4 and $30{ }^{\circ} \mathrm{C}$, respectively (White et al. 1994). Linamarase present in the cassava roots has lower catalytic efficiency than the cassava leaves. Particularly in the leaves, acetone cyanohydrin decomposition can be catalysed by hydroxynitrile lyase (White et al. 1994). Following the volatilisation into the atmosphere or the extraction with water, free cyanide can be removed from the damaged cassava tissues (Tylleskär et al. 1992). Therefore, if cassava is damaged by direct ingestion without prior processing, acetone cyanohydrin can rapidly decompose and release cyanide. Rosling et al. (1992) and Lundquist et al. (1985) revealed that the released cyanide can mainly bind to methemoglobin until it becomes saturated. The unbound cyanide is converted to isothiocyanate by rhodanese in the presence of sulphur-containing amino acids methionine and cysteine (Osuntokun 1980; Schulz 1984; Westley 1988) and subsequently excreted into urine. Boiling, steaming, baking, frying, mechanical drying by the oven, natural drying by the sun, fermentation, steam distillation have been used in cyanide removal (Montagnac et al. 2009). The total cyanide levels ranged from $6.56 \pm 0.03$ to $165.56 \pm 6.89 \mathrm{mg} / \mathrm{kg}$ and these concentrations were slightly lower than that of the total cyanide levels since the total cyanide should comprise all forms of cyanide including free cyanide. The control sample $(\mathrm{CvC})$ recorded lower values for both free and total cyanides. Both free and total cyanide levels varied significantly $(p<0.05)$ from each other.

The cassava samples appeared to be slightly acidic with their $\mathrm{pH}$ values ranging from $5.92 \pm 0.02$ to $6.89 \pm 0.01$ (Table 5). This $\mathrm{pH}$ value favours the hydrolysis of the cyanogenic glycosides as $\mathrm{HCN}$ catalysed by endogenous linamarase (Fasuyi 2005), which increases the free cyanide concentration in the cassava samples. However, the $\mathrm{pH}$ of the control sample $(\mathrm{CvC})$ was 7.01 signifying its neutrality. There was a significant difference $(p<0.05)$ between all the $\mathrm{pH}$ values in the cassava samples.

The conductivity level of the cassava samples ranged between $94.3 \pm 4.02$ and $239.5 \pm 6.27 \mu \mathrm{S} / \mathrm{cm}$ (Table 5). These values do not correlate with the concentration of cyanide present in the samples probably because cyanide might not be the only ions responsible for the conductivity levels as explained above for the water samples. A 
high moisture content ensures easy distribution and movement of free cyanide within the cassava and the surrounding soil. The moisture content also ranged from $51.20 \pm 0.88$ to $59.20 \pm 1.52 \%$ (Table 5 ). The conductivity levels were found to be significant $(p<0.05)$ from each other.

\section{Cyanide levels in the cocoyam samples}

The result of the cocoyam samples in terms of $\mathrm{pH}$, conductivity, moisture content, free and total cyanide concentrations are presented in Table 6.

The free and total cyanide concentrations ranged from $0.75 \pm 0.01$ to $34.56 \pm 0.73$ and $11.13 \pm 0.61$ to $59.00 \pm 0.57 \mathrm{mg} / \mathrm{kg}$, respectively. The lethal dose of hydrogen cyanide in cocoyam was found to be $35.00 \mathrm{mg} / \mathrm{kg}$ (Goesaert et al. 2005), which gives cocoyam a safe margin compared to cassava. According to Anhwange et al. (2011), cocoyam recorded cyanide level of $34.10 \mathrm{mg} / \mathrm{kg}$, while Echendu et al. (2009) also reported $0.87 \mathrm{mg} / \mathrm{kg}$ as cyanide level in cocoyam. Olajide et al. (2011) and Abdulrashid and Agwunobi (2009) found a wide variation ( 2.10 to $17.13 \mathrm{mg} / 100 \mathrm{~g}$ ) of cyanide level in cocoyam. A study reported by Uhegbu et al. (2012) showed higher levels of cyanide $(15.19 \pm 1.61 \mathrm{mg} / \mathrm{kg})$ in cocoyam. Besides several reports on cyanides level in cassava, there has been no established limit for cyanide in cocoyam.

The $\mathrm{pH}$ values of the cocoyam samples ranged from $6.50 \pm 0.06$ to $7.21 \pm 0.04$ (Table 6). The $\mathrm{pH}$ values revealed a direct variation of cyanide concentrations in the samples. Cocoyam like any cyanide-contained plant accumulates cyanide in the form of cyanogenic glycosides. The reactions of these glycosides were affected by $\mathrm{pH}$ with some $\mathrm{pH}$ values fall within the optimum range (2.2 to 9.0) (Nieto-Domínguez et al. 2015). There was a significant difference $(p<0.05)$ between all the $\mathrm{pH}$ values. The conductivity values ranged from $34.3 \pm 0.07$ to $125.9 \pm 6.14 \mu \mathrm{S} / \mathrm{cm}$, while the moisture content ranged from $43.10 \pm 1.70$ to $62.00 \pm 1.68 \%$. A significant difference $(p<0.05)$ were found between conductivity and moisture content.

\section{Health risk assessment \\ Daily intake of cyanide in cassava and cocoyam}

The daily intake of cyanide via the consumption of cassava and cocoyam for adults and children in Kenyasi, a Mining Community in the Brong Ahafo Region of Ghana are shown in Table 7. The daily intake of cyanide was evaluated according to the average concentration of cyanide in each type of food and corresponding consumption rate.

Table 6 Analysis results of cocoyam samples (CyC - control cocoyam sample)

\begin{tabular}{|c|c|c|c|c|c|}
\hline Sample & $\mathrm{pH}$ & Cond. $(\mu \mathrm{S} / \mathrm{cm})$ & Moisture content (\%) & $\mathrm{CN}^{-}(\mathrm{mg} / \mathrm{kg})$ & Total $\mathrm{CN}^{-}(\mathrm{mg} / \mathrm{kg})$ \\
\hline $\operatorname{CyF} 1(\mathrm{I})$ & $6.64 \pm 0.01$ & $112.7 \pm 3.24$ & $49.70 \pm 0.94$ & $34.56 \pm 0.73$ & $47.19 \pm 0.85$ \\
\hline CyF1(II) & $6.52 \pm 0.01$ & $64.3 \pm 1.14$ & $46.50 \pm 0.56$ & $13.44 \pm 0.65$ & $33.69 \pm 0.72$ \\
\hline CyF1(III) & $6.59 \pm 0.04$ & $81.4 \pm 4.20$ & $47.50 \pm 0.87$ & $25.38 \pm 0.87$ & $48.38 \pm 0.40$ \\
\hline CyF1(IV) & $6.71 \pm 0.02$ & $101.3 \pm 6.32$ & $44.30 \pm 1.50$ & $18.13 \pm 0.53$ & $40.00 \pm 0.23$ \\
\hline CyF2(I) & $6.99 \pm 0.02$ & $98.2 \pm 6.12$ & $47.10 \pm 0.87$ & $12.75 \pm 0.24$ & $28.44 \pm 0.35$ \\
\hline $\mathrm{CyF} 2(I)$ & $6.97 \pm 0.01$ & $78.2 \pm 3.12$ & $48.40 \pm 1.68$ & $11.81 \pm 0.41$ & $29.88 \pm 0.61$ \\
\hline CyF2(III) & $7.01 \pm 0.04$ & $121.0 \pm 4.12$ & $50.20 \pm 0.40$ & $4.50 \pm 0.03$ & $30.19 \pm 0.45$ \\
\hline CyF2(IV) & $6.88 \pm 0.05$ & $34.3 \pm 0.07$ & $46.60 \pm 0.60$ & $16.25 \pm 0.06$ & $25.75 \pm 0.74$ \\
\hline CyF3(I) & $6.59 \pm 0.03$ & $64.6 \pm 3.00$ & $46.20 \pm 1.35$ & $22.63 \pm 0.85$ & $36.31 \pm 0.12$ \\
\hline $\mathrm{CyF3}(\mathrm{II})$ & $6.66 \pm 0.04$ & $77.6 \pm 3.40$ & $48.40 \pm 1.35$ & $31.38 \pm 1.12$ & $59.00 \pm 0.57$ \\
\hline CyF3(III) & $6.50 \pm 0.06$ & $59.0 \pm 1.40$ & $52.30 \pm 0.90$ & $27.75 \pm 0.98$ & $43.63 \pm 0.37$ \\
\hline CyF3(IV) & $6.53 \pm 0.05$ & $84.2 \pm 4.21$ & $47.10 \pm 1.42$ & $25.50 \pm 0.65$ & $39.44 \pm 0.42$ \\
\hline CyF4(I) & $7.21 \pm 0.04$ & $74.1 \pm 2.40$ & $45.30 \pm 0.65$ & $0.75 \pm 0.01$ & $11.13 \pm 0.61$ \\
\hline CyF4(II) & $7.03 \pm 0.01$ & $44.9 \pm 0.71$ & $56.37 \pm 0.74$ & $10.63 \pm 0.07$ & $14.63 \pm 0.10$ \\
\hline CyF4(III) & $6.95 \pm 0.01$ & $66.5 \pm 3.17$ & $43.10 \pm 1.70$ & $14.63 \pm 0.24$ & $24.63 \pm 0.42$ \\
\hline CyF4(IV) & $6.85 \pm 0.03$ & $79.2 \pm 3.14$ & $50.10 \pm 0.68$ & $13.13 \pm 0.45$ & $17.94 \pm 0.35$ \\
\hline CyF5(I) & $6.91 \pm 0.01$ & $125.9 \pm 6.14$ & $62.00 \pm 1.68$ & $6.38 \pm 0.03$ & $18.63 \pm 0.71$ \\
\hline CyF5(II) & $6.95 \pm 0.04$ & $47.9 \pm 2.14$ & $54.90 \pm 0.90$ & $6.13 \pm 0.03$ & $13.25 \pm 0.35$ \\
\hline CyF5(III) & $6.93 \pm 0.06$ & $55.8 \pm 2.01$ & $56.70 \pm 1.35$ & $6.19 \pm 0.03$ & $14.06 \pm 0.76$ \\
\hline CyF5(IV) & $6.89 \pm 0.02$ & $49.4 \pm 0.45$ & $53.70 \pm 0.64$ & $6.88 \pm 0.04$ & $16.31 \pm 0.45$ \\
\hline CyC & $6.99 \pm 0.04$ & $50.9 \pm 1.54$ & $59.10 \pm 0.50$ & $0.50 \pm 0.01$ & $0.69 \pm 0.01$ \\
\hline
\end{tabular}


Table 7 Daily intake of cyanide and total cyanide (g/day) via the consumption of cassava and cocoyam

\begin{tabular}{|c|c|c|c|c|c|c|}
\hline \multirow[b]{2}{*}{ Type of food } & \multicolumn{2}{|c|}{ Daily intake $(g / \text { day })^{a}$} & \multicolumn{2}{|l|}{$\mathrm{CN}^{-}$} & \multicolumn{2}{|l|}{$\mathrm{TCN}^{-}$} \\
\hline & Urban & Rural & Adult & Children & Adult & Children \\
\hline Cassava & 112.20 & 196.10 & 57.05 & 74.57 & 425.24 & 555.83 \\
\hline Cocoyam & 72.30 & 44.70 & 26.49 & 50.82 & 197.41 & 378.75 \\
\hline Total & - & - & 83.54 & 125.39 & 622.65 & 934.58 \\
\hline
\end{tabular}

${ }^{\mathrm{a}}$ Whitby (1969)

The daily intake of cyanide from cassava was larger than that from cocoyam. The daily intake of total cyanide for both adult and children via cassava and cocoyam consumption were considerably higher than the provisional tolerable daily intake values. Therefore, the persistent intake of cassava and cocoyam can probably induce adverse health effects. Children contributed the most cyanide and total cyanide intake.

\section{Non-carcinogenic risk assessment of cyanide in different exposures}

Based on the ADD and RfD of cyanide, the non-cancer risks posed by cyanide from the different exposure routes to both adult and children are given in Table 8 . The mean exposure route of cyanide for adult and children increased according to the following order: ingestion > dermal contact. Moreover, the HI results via ingestion and dermal contact with children are $>1$, including fish ingestion by an adult. This signifies adverse non-carcinogenic risk. The $\mathrm{HI}$ values in children were observed to develop more non-carcinogenic risk compared to an adult. This attributed to the fact children tend to have significant contact with soil during their outdoor activities and they are more likely to have a direct hand-to-mouth exposure of cyanide from the mining activities. The data produced in Kenyasi clearly show that cyanide poses significant risks to children via the consumption of fish, cassava and cocoyam. With regard to the water pathways, the highest non-carcinogenic risk was from borehole water ingestion, followed by dam water ingestion. The risk of cyanide by fish ingestion

Table 8 Non-carcinogenic risk of cyanide for both adult and children

\begin{tabular}{llll}
\hline Type & Pathway & Adult & Children \\
\hline Dam water & Ingestion & 0.40 & 2.95 \\
& Dermal & 0.34 & 1.42 \\
Bore hole water & Ingestion & 0.43 & 3.18 \\
& Dermal & 0.35 & 1.52 \\
Cassava & Ingestion & 0.91 & 6.75 \\
Cocoyam & Ingestion & 0.42 & 3.13 \\
Fish & Ingestion & 1.47 & 7.21 \\
\hline
\end{tabular}

was the highest, followed by cassava, and cocoyam. These results illustrate that the more toxic cyanide in the integrated exposure pathway in the study area can also explain the higher non-carcinogenic risks.

\section{Conclusion}

This study was carried out to evaluate the free and total cyanide levels in water, fish, cassava and cocoyam samples, which were collected from Kenyasi in the Brong Ahafo region, a mining community. Physical parameters, such as $\mathrm{pH}$, conductivity, TDS and TSS were determined. The free cyanide levels found in most of the water samples, except at Dam 4, Dam 7 and BH1 were below the acceptable limit of $0.2 \mathrm{mg} / \mathrm{L}$ for drinking water, which indicates that majority of the water samples were safe for drinking. The results from the control samples were all generally lower than those of all the samples. The total cyanide levels recorded from each determination were all higher than levels recorded for the free cyanide. There was a linear relationship between the $\mathrm{pH}$ values and the cyanide levels in all the samples including the control samples. However, there was no significant difference between the total dissolved solids, conductivity or total suspended solids and the water samples. Among all the solid samples, cassava recorded the highest cyanide level followed by fish and cocoyam recording the least. From the results, it can be concluded that fish, cassava and water samples at Dam 4, Dam 7 and BH1 were not safe for consumption since they recorded values higher than the set limits. The daily intake of total cyanide for both adult and children via cassava and cocoyam consumption were considerably higher than the provisional tolerable daily intake values. Moreover, the $\mathrm{HI}$ results via ingestion and dermal contact with children are $>1$, including fish ingestion by an adult. This signifies adverse non-carcinogenic risk. The persistent intake of cassava and cocoyam can probably induce adverse health effects. Therefore, people are advised not to feed on the cassava product, fish and consume water samples located close to the Dam 4, Dam 7 and BH1.

\section{Abbreviations}

ANOVA: Analysis of variance; EC: electrical conductivity; EPA: Environmental Protection Agency; HCN: hydrogen cyanide; LSD: least significant difference; TDS: total dissolved solids; TSS: total suspended solids; USEPA: The United States Environmental Protection Agency

\section{Acknowledgments}

The authors are grateful to the Department of Chemistry, Kwame Nkrumah University of Science and Technology, Kumasi for laboratory resources provided.

\section{Availability of data and materials \\ The data sets on which the conclusions of the paper rely is presented in the main body of the manuscript.}

\section{Authors' contributions}

EEKA, LPA, EKA and FO conceived and designed the study. LPA conducted the study and drafted the manuscript. LPA, EKA and FO contributed to the analysis and interpretation of data. FO contributed to the health risk analysis. 
EEKA, LPA, EKA and FO revised the draft manuscript. All authors read and approved the final manuscript.

\section{Funding}

The National Council for Tertiary Education (NTCE), Ghana under the Teaching and Learning Innovation Fund (TALIFKNUSTR/3/005/2005) funded this work.

\section{Ethics approval and consent to participate}

Not applicable.

\section{Consent for publication}

Not applicable.

\section{Competing interests}

The authors declare that they have no competing interests.

\section{Publisher's Note}

Springer Nature remains neutral with regard to jurisdictional claims in published maps and institutional affiliations.

Received: 29 June 2017 Accepted: 23 October 2017

Published online: 26 October 2017

\section{References}

Abdulrashid M, Agwunobi LN. Taro cocoyam (Colocasia Esculenta) meal as feed ingredient in poultry. Pak J Nutr. 2009;8:668-73.

Anhwange B, Asemave K, Ikyenge B, Oklo D. Hydrogen cyanide content of Manihort Utilissima, Colocasia Esculenta, Dioscorea Bulbifera and Dioscorea Domentorum tubers found in Benue state. Int J Chem. 2011;3:69-71.

APHA. Standard Methods for the Examination of Water and Waste Water. 20th ed: American Water Works Association and Water pollution control Federation; 1998.

Balagopalan C, Padmaja G, Nanda SK, Moorthy SN. Cassava in food, feed, and industry. Boca Raton: CRC Press, Inc:; 1988. p. 190-194

Bruckner AW, Roberts GG. Proceedings of the International Cyanide Detection Testing Workshop. Silver Spring, MD: OAA Technical Memorandum NMFSOPR-40; 2008.

Chabukdhara M, Nema AK. Heavy metals assessment in urban soil around industrial clusters in Ghaziabad, India: probabilistic health risk approach. Ecotoxicol Environ Saf. 2013;87:57-64.

Doudoroff $P$, Leduc $G$, Schneider CR. Acute toxicity to fish of solutions containing complex metal cyanides, in relation to concentrations of molecular hydrocyanic acid. Trans Am Fish Soc. 1966;95:6-22.

Dube P, Hosetti B. Behavior surveillance and oxygen consumption in the freshwater fish Labeo Rohita (Hamilton) exposed to sodium cyanide. Biotech Anim Husbandry. 2010;26:91-103.

Echendu C, Obizoba I, Ngwu E, Anyika J. Chemical composition of Groundbean based cocoyam, yam and plantain pottage dishes and roasted Groundbean. Pak J Nutr. 2009:8:1786-90.

Eisler R, Wiemeyer SN. Cyanide hazards to plants and animals from gold mining and related water issues. Rev Environ Contam Toxicol: Springer; 2004. p. 21-54.

Environmental site assessment guideline. DB11/T 656-2009; 2009.

Fasuyi AO. Nutrient composition and processing effects on cassava leaf (Manihot Esculenta, Crantz) antinutrients. Pak J Nutr. 2005;4:37-42.

Fillo J, Koraido S, Evans J. Sources, characteristics, and management of produced waters from natural gas production and storage operations. Produced Water: Springer: 1992. p. 151-61.

Flynn CM, Haslem SM. Cyanide chemistry: precious metals processing and waste treatment: US Department of the Interior, Bureau of Mines; 1995.

Goesaert H, Brijs K, Veraverbeke W, Courtin C, Gebruers K, Delcour J. Wheat flour constituents: how they impact bread quality, and how to impact their functionality. Trends Food Sci Technol. 2005;16:12-30.

Government of Ghana. Ghana Districts; 2009. http://www.ghanadistricts.com/ Accessed 25 Oct 2017.

Govind P. Toxicity of cyanide in fishes: an overview. Universal J Pharm. 2013;2:23-6.

Hosetti B. Metabolic changes in the freshwater fish Catla Catla, under copper cyanide intoxication. Int J Pharm Biol Arch. 2011;2:874-9.

Ikuta K, Amano M, Kitamura S. Effects of acid rain on inland water ecosystemeffects on fish. Environ Sci. 1999;12:259-64.
Ikuta K, Shikama T, Oda S, Okumoto N. Acid tolerance of eyed embryos and larvae in salmonid fishes. Bull Natl Res Inst Aquacult. 1992;21:39-45.

Latkowska B, Figa J. Cyanide removal from industrial waste waters. J Environ Stud. 2007:16:748-52

Lundquist P, Rosling H, Sörbo B. Determination of cyanide in whole blood, erythrocytes, and plasma. Clin Chem. 1985;31:591-5.

Meeussen JC, Keizer MG, van Riemsdijk WH, de Haan FA. Solubility of cyanide in contaminated soils. J Environ Qual 1994;23:785-792.

Montagnac JA, Davis CR, Tanumihardjo SA. Processing techniques to reduce toxicity and antinutrients of cassava for use as a staple food. Compr Rev Food Sci Food Saf. 2009;8:17-27.

Moran R. Cyanide uncertainties: observations on the chemistry, toxicity and analysis of cyanide in mining-related waters: mineral policy center; 1998.

Morrison S, Sosnoff JJ, Heffernan KS, Jae SY, Fernhall B. Aging, hypertension and physiological tremor: the contribution of the cardioballistic impulse to tremorgenesis in older adults. J Neurol Sci. 2013;326:68-74.

Mudder TI, Botz M, Smith A. Chemistry and treatment of cyanidation waste. London, UK: Mining Journal Books; 2001

Nagasawa HT, Goon DJ, Crankshaw DL, Vince R, Patterson SE. Novel, orally effective cyanide antidotes. J Med Chem. 2007;50:6462-4.

Ndur SA, Amegbey NA. Surface water quality at Boete slimes dam. Int J Environ Monit Anal. 2013;1:53-7.

Newmont Mining Corporation. Ahafo Project, Ghana; 2006. http://www. newmont.com/operations-and-projects/africa/ahafo-ghana/overview/default. aspx. Accessed 25 Oct 2017.

Nieto-Domínguez M, de Eugenio LI, Barriuso J, Prieto A, de Toro BF, CanalesMayordomo Á, Martínez MJ. Novel pH-stable glycoside hydrolase family $3 \beta$ xylosidase from talaromyces amestolkiae: an enzyme displaying regioselective transxylosylation. Appl Environ Microbiol. 2015;81:6380-92.

Obiri S, Dodoo D, Okai-Sam F, Essumang D. Determination of free cyanide and total cyanide concentrations in surface and underground waters in Bogoso and its surrounding areas in Ghana. Bull Chem Soc Ethiop. 2007:21:213-20.

Olajide R, Akinsoyinu A, Babayemi O, Omojola A, Abu A, Afolabi K. Effect of processing on energy values, nutrient and anti-nutrient components of wild cocoyam (Colocasia Esculenta (L.) Schott) corm. Pak J Nutr. 2011;10:29-34.

OSHA. Occupational safety and health standards, Toxic and hazardous substances: Code of Federal Regulations 29 CFR 1910.1000; 1998.

Osuntokun B. Cassava diet, chronic cyanide intoxication and neuropathy in the Nigerian Africans. In: Human nutrition and diet, vol 36. Karger publishers; 1980. p. 141-173.

Pritchard J. Hydrogen cyanide toxicological overview. Health Protection Agency, CHAPD HQ. 2007

Rosling H, Mlingi N, Tylleskär T, Banea M Causal mechanisms behind human diseases induced by cyanide exposure from cassava. In: Roca, William M: thro, Ann Marie (eds.). International scientific meeting cassava biotechnology network (1, 1992, Cartagena de Indias, Colombia); 1992. p. 366-375.

Sawaraba I, Rao BR. Monitoring of river water for free cyanide pollution from mining activity in Papua New Guinea and attenuation of cyanide by biochar. Environ Monit Assess. 2015;187:4181.

Schulz V. Clinical pharmacokinetics of nitroprusside, cyanide, thiosulphate and thiocyanate. Clin Pharmacokinet. 1984;9:239-51.

Tylleskär T, Rosling H, Banea M, Bikangi N, Cooke R, Poulter N. Cassava cyanogens and konzo, an upper motoneuron disease found in Africa. Lancet. 1992;339: 208-11.

Ubalua AO. Cyanogenic glycosides and the fate of cyanide in soil. Aust J Crop Sci. 2010;4:223.

Uhegbu FO, Akubugwo E, Iweala E. Effect of garri processing effluents [waste water] on the cyanide level of some root tubers commonly consumed in the south east of Nigeria. Afr J Food Agric Nutr Dev. 2012;12:6748-58.

United State Department of Health and Human Services (USDHHS). Public Health Service, Agency for Toxic Substances and Disease Registry. Toxicological Profle for Cyanide, PB2007-100674. Atlanta: Agency for Toxic Substances and Disease Registry; 2006.

United States Environmental Protection Agency (USEPA). Ambient water quality criteria for cyanide-1984. Arehington: Office of Water Regulations and Standards Criteria and Standard Division; 1984.

United States Environmental Protection Agency (USEPA). National primary drinking water standards. Arehington: Office of Research and Development; 2002.

USEPA. Risk assessment guidance for Superfund. Human health evaluation manual, (part A), vol 1. Office of emergency and remedial response, Washington, DC; 1989. 
USEPA. Reference Dose (RfD): description and use in health risk assessments. Background document 1A. Integrated risk information system (IRIS); 1993.

USEPA. Exposure Factors handbook. National Center for environmental assessment. United state. Washington, DC: Environmental Protection Agency; 2011.

USEPA IRIS. Integrated Risk Information System. Environmental Protection Agency Region I. USEPA, Washington DC; 2011.

Vaz MC, Rocha-Santos TA, Rocha RJ, Lopes I, Pereira R, Duarte AC, et al. Excreted thiocyanate detects live reef fishes illegally collected using cyanide-a noninvasive and non-destructive testing approach. PLoS One. 2012;7:e35355.

Weber-Scannell PK, Duffy LK. Effects of total dissolved solids on aquatic organism: a review of literature and recommendation for salmonid species. Am J Environ Sci. 2007:3:1-6.

Westley J. Mammalian cyanide detoxification with sulphane sulphur. Cyanide compounds in biology. Chichester, John Wiley; 1988.

Whitby P. A Review of information concerning food consumption in Ghana. FAO, Rome; 1969.

White WL, McMahon JM, Sayre RT. Regulation of cyanogenesis in cassava. Acta Hortic. 1994;375:69-77.

Wilson J. Cyanide in human disease: a review of clinical and laboratory evidence. Fundam Appl Toxicol. 1983;3:397-9.

Yen D, Tsai J, Wang L-M, Kao W-F, S-C H, Lee C-H, et al. The clinical experience of acute cyanide poisoning. Am J Emerg Med. 1995;13:524-8.

\section{Submit your manuscript to a SpringerOpen ${ }^{\circ}$ journal and benefit from:}

- Convenient online submission

- Rigorous peer review

- Open access: articles freely available online

- High visibility within the field

- Retaining the copyright to your article

Submit your next manuscript at $>$ springeropen.com 